\title{
Heterogeneous Pathways of Oxidizing Radical Production in Human Neutrophils and the HL-60 Cell Line
}

\author{
PETER E. NEWBURGER AND ALFRED I. TAUBER ${ }^{(34)}$ \\ Department of Pediatrics, University of Massachusetts Medical School, Worcester, Massachusetts; \\ Department of Medicine, Harvard Medical School, Boston, Massachusetts; and the Hematology Division, \\ Department of Medicine, and Department of Rheumatology and Immunology, Brigham and Women's Hospital, Boston, \\ Massachusetts, USA
}

\begin{abstract}
Summary
Oxygen-derived free radicals with hydroxyl radical $(\mathrm{OH} \bullet)$-like reactivity are products of the human neutrophil respiratory burst. Such radicals, although dependent on $\mathrm{O}_{2}{ }^{-}$generation arise from complex oxidation reactions that may be independent of an ironor lactoferrin-catalyzed Haber-Weiss mechanism. Differentiated HL-60 promyelocytic leukemia cells completely deficient in lactoferrin generate oxidizing radicals at a rate greater than that of human neutrophils, indicating lactoferrin-independent pathways for $\mathrm{OH} \cdot$ generation. The further heterogeneity of pathways generating $\mathrm{OH} \cdot$ activity in neutrophils is indicated by the cell concentration dependence of the reaction, the variability of $\mathrm{H}_{2} \mathrm{O}_{2}$ as a precursor reactant, and the various proportions of oxidizing radical activity to $\mathrm{O}_{2}{ }^{-}$detected in human neutrophils stimulated to a variety of agonists
\end{abstract}

\section{Speculation}

The ethylene assay for oxidizing radical activity may detect different classes of oxidizing species capable of reacting with the aldehyde substrate. The complexity of defining the oxygen-derived radicals of the ethylene assay suggests methodologic difficulties of either quantitating or precisely defining the radicals generated in the respiratory burst by this method.

The generation of oxygen-derived free radicals by the human neutrophil respiratory burst is critical for normal microbicidal processes (4). Superoxide $\left(\mathrm{O}_{2}{ }^{-}\right)$, the one electron reduction product of molecular oxygen is generated by a flavoenzyme, activated by phagocytic or soluble stimuli (16). $\mathrm{O}_{2}{ }^{-}$in turn dismutates spontaneously or catalytically with superoxide dismutase (SOD) to form $\mathrm{H}_{2} \mathrm{O}_{2}$. In the presence of myeloperoxidase and halide anion, $\mathrm{H}_{2} \mathrm{O}_{2}$ forms an effective microbicidal system (4). Hydroxyl radical $(\mathrm{OH} \cdot)$, another free radical produced in the respiratory burst (28), also appears to be a potent bactericidal species (14). The pathways by which $\mathrm{OH} \cdot$ is formed in the human neutrophil are as yet unresolved.

Our initial demonstration of the production of oxygen-derived species with $\mathrm{OH}$ - reactivity by stimulated intact human neutrophils (26) and particulate preparations (29) utilized an indirect assay system in which the oxidation of either methional or 4ketomethiobutyric acid (KMB) to form ethylene is quantitated by gas chromatography. $\mathrm{O}_{2}^{-}$appeared to be the precursor for the formation of ethylene, whereas $\mathrm{H}_{2} \mathrm{O}_{2}$ played only a minor direct role. We postulated that $\mathrm{O}_{2}{ }^{-1}$ reacts with organic hydroperoxides to form a variety of oxidizing radicals in addition to $\mathrm{OH} \cdot$, all of which would be detected in the assay as they react with methional or $\mathrm{KMB}$ to form ethylene. Using electron spin resonance spectroscopy, OH. spin trap signals have been detected with stimu- lated neutrophils (24), but because of the technical difficulties of this method, the signal could be a degradative product.

The Haber-Weiss reaction $\left(\mathrm{O}_{2}^{-}+\mathrm{H}_{2} \mathrm{O}_{2} \rightarrow \mathrm{O}_{2}+\mathrm{OH} \cdot+\mathrm{OH}^{-}\right)$ has been postulated as the source of $\mathrm{OH}$ - in the respiratory burst, but the spontaneous rate of $\mathrm{OH}$. generation by this pathway appears insufficient. Iron salts and chelates have been shown to catalyze the Haber-Weiss reaction in pure biochemical systems (17):

$$
\begin{gathered}
\mathrm{O}_{2}^{-}+\mathrm{Fe}^{+++} \rightarrow \mathrm{O}_{2}+\mathrm{Fe}^{++} \\
\mathrm{H}_{2} \mathrm{O}_{2}+\mathrm{Fe}^{++} \rightarrow \mathrm{OH} \cdot+\mathrm{OH}^{-}+\mathrm{Fe}^{++} \\
\hline \text { Net reaction: } \mathrm{O}_{2}^{-}+\mathrm{H}_{2} \mathrm{O}_{2} \rightarrow \mathrm{O}_{2}+\mathrm{OH} \cdot+\mathrm{OH}^{-}
\end{gathered}
$$

Recently, lactoferrin, an iron-binding neutrophil granule protein, has been proposed as an iron source for the catalysis of the reaction in the neutrophil respiratory burst (2).

In order to further define the role of lactoferrin in the production of $\mathrm{OH}$. in a Haber-Weiss reaction, we have studied ethylene generation by a lactoferrin-deficient cell line. HL-60 promyelocytic leukemia cells differentiate in vitro in response to polar solvents and other inducing agents (7) to produce mature neutrophils capable of a respiratory burst, ingestion, chemotaxis, and bacterial killing $(8,18,12)$. These cells contain no detectable lactoferrin by immunodiffusion (18) or radioimmunoassay (12) and, in fact, lack another secondary granule marker, vitamin $B_{12}$ binding protein, and morphologically recognizable secondary granules altogether (12). Thus, the ability of differentiated HL-60 cells to generate ethylene from KMB indicates a lactoferrin-independent pathway for the production of this oxidizing radical pathway.

Ethylene generation also occurs upon stimulation of normal neutrophils by latex particles, which differ from other commonly employed stimuli in the ratios of reduced oxygen metabolites generated. $\mathrm{H}_{2} \mathrm{O}_{2}$ appears to be a primary precursor for $\mathrm{OH} \cdot-$ like oxidizing radicals in cells stimulated by latex but not in those stimulated by opsonized zymosan (OZ) or phorbol myristate acetate (PMA). This unique dependence on $\mathrm{H}_{2} \mathrm{O}_{2}$ in latex-stimulated cells, suggests either a different source or pathway for the generation of radical species with the same reactivity of $\mathrm{OH}$. The complexity of defining the oxygen-derived radicals of the ethylene assay suggests methodologic difficulties of either quantitating or precisely defining the radicals generated in the respiratory burst by this method.

\section{MATERIALS AND METHODS}

Catalase (Sigma C-40, thymol-free), $N$-ethyl maleimide, KMB, zymosan, and cytochrome $c$ Type VI were obtained from Sigma Chemical Co., St. Louis, MO. SOD was purchased from Truett Laboratories, Dallas, TX, and from Sigma; Hanks' balanced salt solution (HBSS) without phenol red, from GIABCO, Grand 
Island, NY; phorbol myristate acetate, from Consolidated Midland Chemicals, Brewster, NY; L-tryptophan, Calbiochem, Los Angeles, $\mathrm{CA}$; and dimethylformamide and dimethyl-sufoxide from Fisher Scientific Co., Pittsburgh, PA. Polystyrene/toluene latex particles $(2.77 \mu)$ were purchased from Dow Chemical Corp., Midland, MI. These and all other reagents were the best grade commerically available and were used without further purification. PMA was prepared as a $0.2 \mathrm{mg} / \mathrm{ml}$ stock solution in dimethylsulfoxide and stored at $-20^{\circ} \mathrm{C}$ in the dark. Fresh aqueous solutions in HBSS or phosphate-buffered saline (PBS), pH 7.4, were prepared daily. Stock solutions of KMB $(0.1 \mathrm{M})$ were prepared daily and stored at $0^{\circ} \mathrm{C}$ until use. Water for all solutions was distilled and deionized in a Bornstead demineralizer column (Fisher Scientific Co.) PBS and HBSS contained less than $0.5 \mu \mathrm{g} / \mathrm{ml}$ iron by atomic absorption spectroscopy.

Preparation of cells and phagocytosable particles. HL-60 cells (generously provided by R.C. Gallo) were grown as previously described (18) in RPMI-1640 medium (M.A. Bioproducts, Walkersville, MD) plus $10 \%$ fetal bovine serum (M.A. Bioproducts), with or without exposure to $60 \mu \mathrm{M}$ dimethylformamide for the designated number of days. Purified neutrophils were harvested as previously described (16) by sedimentation in Dextran T-500 and centrifugation through Ficoll-Paque (both from Pharmacia Fine Chemicals, Piscataway, NJ). Zymosan was opsonized in autologous serum as previously described (2) and then suspended at a concentration of $60 \mathrm{mg} / \mathrm{ml}\left(4.6 \times 10^{9}\right.$ particles $\left./ \mathrm{ml}\right)$. Latex particles were dialyzed 3 times against 1 liter $0.9 \% \mathrm{NaCl}$ at $4^{\circ} \mathrm{C}$ for $48 \mathrm{~h}$, and then stored at a concentration of $3 \times 10^{9}$ particles/ $\mathrm{ml}$ in $0.9 \% \mathrm{NaCl}$.

Ethylene production. Ethylene production by cells was measured by gas chromatography using a modification of the method of Beauchamp and Fridovich (5) as previously described (24). Incubations were conducted in 3.5-ml siliconized tubes. KMB (2.5 $\mathrm{mM}), 5 \times 10^{6}$ cells, and SOD, catalase, or other scavengers as indicated were pre-incubated for $3 \mathrm{~min}$ at $37^{\circ} \mathrm{C}$ in a shaking incubator. PMA (80 ng), OZ $\left(1.5 \times 10^{8}\right.$ particles $)$, or latex $\left(10^{8}\right.$ particles) were then added to a final reaction volume of $1.0 \mathrm{ml}$. (Preliminary experiments established these concentrations for maximal ethylene production). The tubes were stopped with serum ports sealed with silcone grease, and the incubations were continued for the time intervals noted, after which the reactions were terminated by placing the tubes in melting ice. Using a Hamilton gas-tight syringe, $0.25-\mathrm{ml}$ samples of the gas overlying the reaction mixtures were withdrawn and subjected to gas chromatography at a temperature of $100^{\circ} \mathrm{C}$ on Chromosorb 102 packed in a 6 feet long $x 1 / 4$ inch diameter glass column, using $\mathrm{N}_{2}$ at $40 \mathrm{psi}$ as the carrier gas (Perkin Elmer, Norwalk, CT, 3920 gas chromatograph with flame ionization detector). Ethylene in $\mathrm{N}_{2}(109 \mathrm{ppm})$ (Supelco, Inc., Bellefonte, PA) was used for daily calibration to quantitate sample ethylene concentration, as previously described (28).

Cytochrome $c$ reduction. We adapted the method of Babior et al. (3) for discontinuous measurement of $\mathrm{O}_{2}^{-}$-dependent cytochrome $c$ reduction. Reaction mixtures contained cells $\left(5 \times 10^{6}\right)$, ferricytochrome $c(100 \mu$ moles $)$, and PMA ( $80 \mathrm{ng})$ in $10 \mathrm{ml}$ PBS with glucose $(5 \mathrm{mM})$ at $37^{\circ} \mathrm{C}$ in plastic tubes, and incubated in a shaker-water bath at $37^{\circ} \mathrm{C}$. At the designated times after addition of PMA, the tubes were vortex mixed and $0.9-\mathrm{ml}$ samples removed into cold $0.1 \mathrm{M} \mathrm{N}$-ethyl malemide. Samples were centrifuged 1 $\min$ at $15,000 \times g$ in an Eppendorf microfuge and the supernatant fraction read in a Perkin-Elmer model 552 spectrophotometer. $\mathrm{O}_{2}{ }^{-}$-dependent cytochrome $c$ reduction was calculated from the difference in $\mathrm{A}_{550}$ between triplicate tubes with and without SOD divided by the nanomolar extinction coefficient for the reduction of cytochrome $c(\Delta \varepsilon \mathrm{nM}=0.021)$. Rates of $\mathrm{O}_{2}{ }^{-}$generation were continuously measured as previously described (19) with the same reagents with or without designated scavengers in the sample and reference cuvettes of the spectrophotometer. Rates were calculated from the rate of change of the difference spectrum at $550 \mathrm{~nm}$.

Hydrogen peroxide production. In parallel with cytochrome $c$ reduction assays, we incubated identical reaction mixtures of cells and PMA in buffer without cytochrome $c$ containing sodium azide $(5 \mathrm{mM})$. At the indicated times, $0.9-\mathrm{ml}$ samples were removed into $0.1 \mathrm{ml} \mathrm{10 \%} \mathrm{trichloroacetic} \mathrm{acid} \mathrm{and} \mathrm{assayed} \mathrm{for} \mathrm{peroxide} \mathrm{by} \mathrm{the}$ ferrithiocyanate method (30).

\section{RESULTS}

Ethylene generation by HL-60 cells. Differentiated HL-60 cells generated ethylene from KMB in response to PMA stimulation (Table 1), producing slightly over twice as much KMB-oxidizing radicals as control neutrophils. They reduced $47 \%$ as much cytochrome $c$ as neutrophils over the same incubation period, confirming the previously described relative rates of PMA-stimulated $\mathrm{O}_{2}{ }^{-}$ production by mature HL- 60 cells and neutrophils (18); thus, the ratio of ethylene production to cytochrome $c$ reduction was higher in HL-60 cells than in neutrophils ( $0.4 \%$ versus $0.1 \%$, respectively). Similar results were obtained with $\mathrm{OZ}$ stimulation. As shown in Figure 1, ethylene production by PMA-stimulated HL-60 cells ran parallel to cytochrome $c$ reduction over $45 \mathrm{~min}$ after stimulation. Both processes demonstrated linearity with cell concentrations of $1-5 \times 10^{6}$ cells $/ \mathrm{ml}$. At greater than $5 \times 10^{6}$ cells $/ \mathrm{ml}$, neutrophils exhibited less ethylene production than that seen at $5 \times 10^{6}$ cells/ $\mathrm{ml}$, a finding previously noted with methional as a substrate (3).

As HL-60 cells mature in culture with a polar solvent inducing agent, they progressively develop markedly increased capacities for phagocytic function (13). As shown in Figure 2, HL-60 cells cultured for 6 or 9 days in a medium containing $60 \mu \mathrm{M}$ dimethylformamide produce six times as much ethylene as uninduced ("Day 0") cells. Cells in their third day of incubation show an intermediate level. This developmental pattern is identical to that previously reported for induction of $\mathrm{O}_{2}{ }^{-}$production in these cells (18) except that, as noted above, mature HL-60 cells surpass neutrophils in ethylene but not in $\mathrm{O}_{2}{ }^{-}$generation. Uninduced $\mathrm{HL}$ 60 cells show a small but measurable respiratory burst in both assay systems.

The effects of scavengers of active oxygen metabolites appear in Table 2. HL-60 cells and neutrophils exhibited similar patterns of inhibition of ethylene generation. Mannitol and tryptophan inhibited ethylene generation respective to their $\mathrm{OH}$ - reactivity (9). L-Histidine at concentrations of $0.1 \mathrm{mM}$, a scavenger of singlet oxygen (13), did not affect ethylene production. SOD dramatically reduced ethylene generation; its inhibitory activity was diminished but not eliminated by autoclaving. Catalase slightly inhibited ethylene generation by HL- 60 cells but not by neutrophils. Albumin at the same protein concentration had no significant effect. Rates of cytochrome $c$ reduction by HL-60 cells and neutrophils were unaffected by any of these scavengers except for SOD, which completely abolished detectable activity. Autoclaved SOD inhibited cytochrome $c$ reduction by $12-15 \%$.

Ethylene generation by neutrophils. Maximal stimulation by polystyrene latex particles, relative to $\mathrm{OZ}$, generates much lower quantities of $\mathrm{O}_{2}^{-}$, as detected in the extracellular cytochrome $c$ assay. Whereas latex stimulated cells produced $6 \%$ of the detected $\mathrm{O}_{2}{ }^{-}$of $\mathrm{OZ}$-stimulated cells, hexose monophosphate shunt activity and $\mathrm{H}_{2} \mathrm{O}_{2}$ generation are comparable (27, J.T. Curnutte and A.I.

Table 1. Ethylene generation, cytochrome $c$ reduction, and hydrogen peroxide production by HL-60 cells and neutrophils ${ }^{1}$

\begin{tabular}{lcc}
\hline & HL-60 & Neutrophils \\
\hline $\begin{array}{l}\text { Ethylene production (nmole } / 30 \\
\text { min } / 5 \times 10^{6} \text { cells) }\end{array}$ & $1.63 \pm 0.37$ & $0.71 \pm 0.16$ \\
$\begin{array}{l}\text { Cytochrome } c \text { reduction (nmole } / 30 \\
\quad \text { min } / 5 \times 10^{6} \text { cells) }\end{array}$ & $377 \pm 18$ & $798 \pm 18$ \\
$\begin{array}{l}\text { Hydrogen peroxide production (nmole } / 30 \\
\text { Hog }\end{array}$ & $244 \pm 24$ & $470 \pm 61$
\end{tabular}
$\min / 5 \times 10^{6}$ cells)

${ }^{1}$ Data are expressed as the mean \pm S.D. of three experiments on separate days. The assays were performed in parallel with the same cells and reagents. For both measurements, HL-60 cells (day 6 in $60 \mu \mathrm{M}$ dimethylformamide) and neutrophils were stimulated by phorbol myristate acetate $(80 \mathrm{ng} / \mathrm{ml})$ as described in "Materials and Methods." 


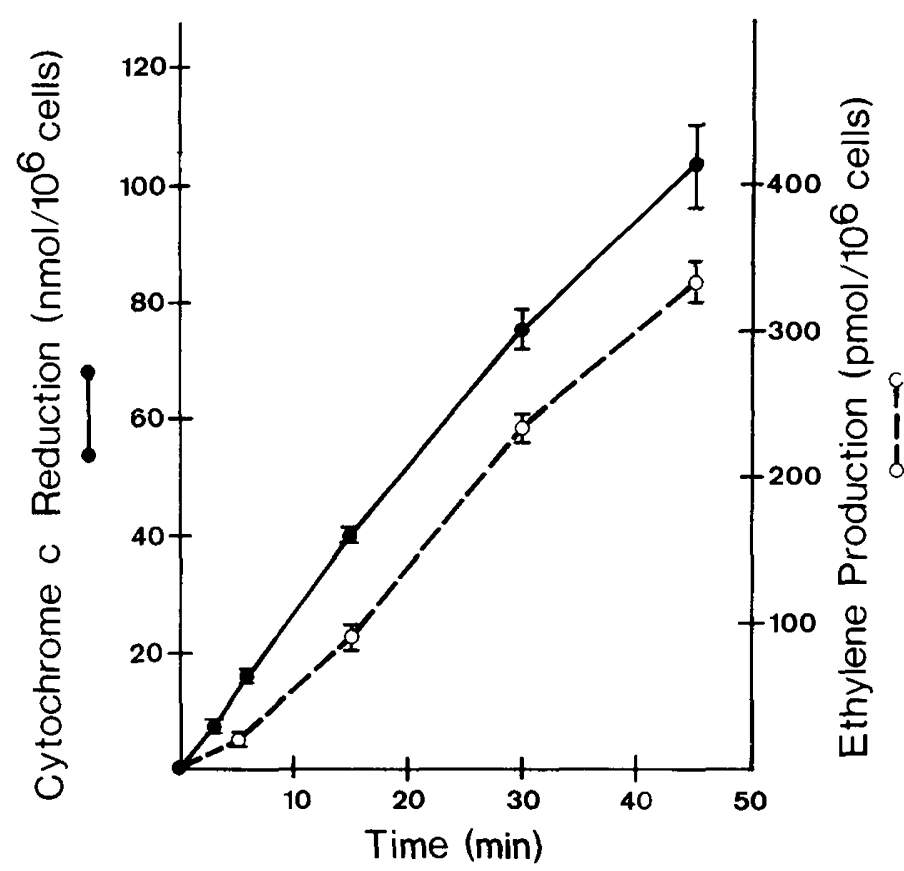

Fig. 1. Cythchrome $c$ reduction and ethylene generation by mature HL-60 cells. HL-60 cells (day 6 in $60 \mu \mathrm{M}$ dimethylformamide) were stimulated by phorbol myristate acetate $(80 \mathrm{ng} / \mathrm{ml})$ and assays performed as described in "Materials and Methods" at the designated times after addition of phorbol myristate acetate. Points represent the means and bars the S.D. of triplicate determinations.

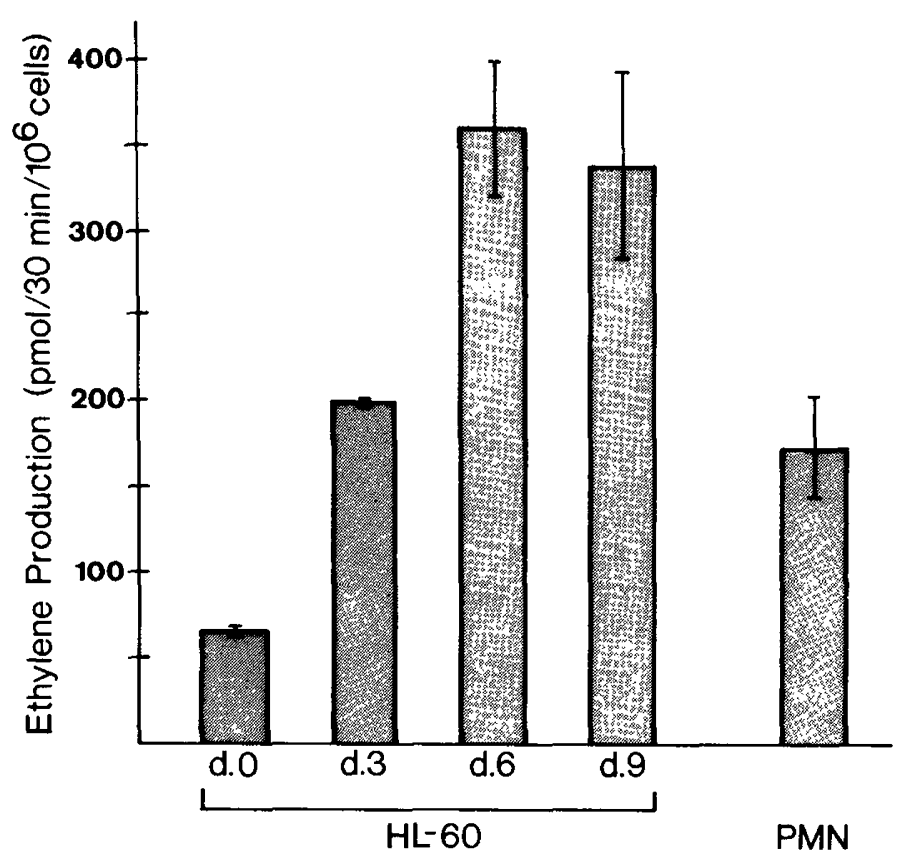

Fig. 2. Ethylene production by HL-60 cells during induced differentiation. HL-60 cells cultured for the indicated number of days in $60 \mu \mathrm{M}$ dimethylformamide and human peripheral blood neutrophils (PMN) were assayed for phorbol myristate acetate-stimulated ethylene generation from 4-ketomethiobutyric acid as described in "Materials and Methods." Bars and error lines indicate mean \pm S.D. for duplicate experiments.

Tauber, unpublished data). Similar quantities of ethylene are generated by PMA, latex, and OZ-stimulated neutrophils (Tables 2 and 3 ), over $30 \mathrm{~min}$, but the profiles of scavenger inhibition are different. SOD efficiently inhibits ethylene production in all cases. Catalase was an effective inhibitor of ethylene generation in latexstimulated neutrophils but not in OZ- or PMA-stimulated cells.
Table 2. Effects of Scavengers of Active Oxygen Species on Ethylene Generation by PMA-Stimulated HL-60 Cells and Neutrophils ${ }^{1}$

\begin{tabular}{lcc}
\hline & \begin{tabular}{c} 
HL-60 (pmole \\
ethylene/30 min/5 \\
\multicolumn{1}{c}{ Agent }
\end{tabular} & $\begin{array}{c}\text { Neutrophils } \\
(\% \text { Control) }\end{array}$ \\
\hline None & $1630 \pm 370(100 \%)$ & $712 \pm 167(100 \%)$ \\
Mannitol $(50 \mathrm{mM})$ & $636 \pm 174(39 \%)^{2}$ & $414 \pm 151(58 \%)^{2}$ \\
Tryptophan $(1 \mathrm{mM})$ & $182 \pm 17(11 \%)^{2}$ & $138 \pm 12(19 \%)^{2}$ \\
L-Histidine $(0.1 \mathrm{mM})$ & $1499 \pm 327(92 \%)$ & $690 \pm 114(97 \%)$ \\
Superoxide dismutase $(30 \mathrm{ng} /$ & $133 \pm 33(8 \%)^{2}$ & $64 \pm 19(9 \%)$ \\
$\quad$ ml) & & \\
$\quad$ autoclaved & $1076 \pm 441(66 \%)^{3}$ & $531 \pm 102(75 \%)^{3}$ \\
Catalase $(1000 \mu / \mathrm{ml})$ & $1160 \pm 177(71 \%)$ & $659 \pm 67(93 \%)$ \\
Albumin $(50 \mu \mathrm{g} / \mathrm{ml})$ & $1735 \pm 460(108 \%)$ & $657 \pm 127(92 \%)$ \\
\hline
\end{tabular}

${ }^{1}$ The results represent mean \pm S.D. of three experiments on separate days. HL-60 cells (day 6 in $60 \mu \mathrm{M}$ dimethylformamide) and neutrophils were stimulated by phorbol myristate acetate $(80 \mathrm{ng} / \mathrm{ml})$ and ethylene generation from 4-ketomethiobutyric acid measured as described in "Materials and Methods."

${ }^{2}$ Value significantly different from control at $P<0.001$ by paired $t$ test.

${ }^{3}$ Value significantly different from control at $P<0.02$ by paired $t$ test.

Table 3. Inhibitor profiles for ethylene generation by latex-and zymosan-stimulated neutrophils

\begin{tabular}{lcc}
\hline & \multicolumn{2}{c}{$\%$ control activity } \\
\hline Latex & $100^{1}$ & $(n=5)$ \\
+ superoxide dismutase $(10 \mu \mathrm{g} / \mathrm{ml})$ & $10.9 \pm 7.7^{2}$ & $(n=5)$ \\
+ catalase $(1000 \mu / \mathrm{ml})$ & $12.3 \pm 7.8^{2}$ & $(n=5)$ \\
+ boiled catalase $(1000 \mu / \mathrm{ml})$ & $104.8 \pm 24.7$ & $(n=3)$ \\
+ tryptophan $(1 \mathrm{mM})$ & $13.5 \pm 10.3^{2}$ & $(n=3)$ \\
Opsonized zymosan & 100 & $(n=5)$ \\
+ superoxide dismutase $(10 \mu \mathrm{g} / \mathrm{ml})$ & $9.1 \pm 6.1^{2}$ & $(n=5)$ \\
+ catalase $(1000 \mu / \mathrm{ml})$ & $67.9+14.9^{3}$ & $(n=5)$ \\
+ boiled catalase $(1000 \mu / \mathrm{ml})$ & $118.6 \pm 18.1$ & $(n=3)$ \\
+ tryptophan $(1 \mathrm{mM})$ & $11.9 \pm 2.5^{2}$ & $(n=3)$ \\
\hline
\end{tabular}

${ }^{1}$ Expressed as pmole $/ 5 \times 10^{6}$ peripheral blood neutrophils $/ 30 \mathrm{~min}$, mean \pm S.D. of five experiments on separate days are: resting cells, 53.8 \pm 23.2 ; latex stimulated, $697.8 \pm 247.0$; and opsonized zymosan stimulated, $710.4 \pm 178.8$.

${ }^{2}$ Value significantly different from control at $P<0.001$ by paired $t$ test.

${ }^{3}$ Value significantly different from control at $P<0.02$ by paired $t$ test.

The stimulus dependence of the catalase effects indicates a primary difference in the role of $\mathrm{H}_{2} \mathrm{O}_{2}$ in the formation of oxidizing radicals with these stimuli.

\section{DISCUSSION}

The primary reaction of the respiratory burst of phagocytosis is the one-electron reduction of molecular oxygen to superoxide, $\mathrm{O}_{2}{ }^{-}$ $(1,3) . \mathrm{O}_{2}{ }^{-}$in turn is metabolized to $\mathrm{H}_{2} \mathrm{O}_{2}, \mathrm{OH} \cdot$, and perhaps other oxidizing free radicals. A frequently-cited means for $\mathrm{OH}$. formation is an iron-catalyzed Haber-Weiss reaction, for which lactoferrin has been proposed as a catalyst $(2,17)$.

The efficient production of ethylene by mature HL- 60 cells, in which lactoferrin is absent, indicates that lactoferrin is not essential for PMA- or OZ-stimulated oxidizing radical production. Ambruso and Johnston (2) have shown that lactoferrin is sufficient for the enhancement of $\mathrm{OH}$ - -like reactivity by both whole neutrophils and cell-free $\mathrm{O}_{2}{ }^{-}$-generating systems. The current findings indicate that cells such as HL-60-derived granulocytes possess effective alternative pathways for oxidizing radical production. Such pathways must also be present in mononuclear phogocytes, which do not contain lactoferrin but do generate oxidizing radicals (23).

Our studies comparing stimulation with PMA and OZ indicate that these pathways are diverse and stimulus-dependent. $\mathrm{O}_{2}{ }^{-}$is a precursor of ethylene production in the human neutrophil, as 
demonstrated by the efficient inhibition by SOD with all stimuli of the respiratory burst. The importance of $\mathrm{H}_{2} \mathrm{O}_{2}$, however, varies with the stimulus. In zymosan- and PMA-activated cells, the inhibition by catalase is relatively minor. Latex-stimulated cells (by a mechanism which is not understood), produce relatively little $\mathrm{O}_{2}{ }^{-}$as detected in the extracellular cytochrome $c$ assay, but generate quantities of $\mathrm{H}_{2} \mathrm{O}_{2}$ comparable to zymosan-stimulated cells (27). In this setting, catalase is almost as effective as SOD in inhibiting ethylene production; thus, in the latex-stimulated cells only, the extracellular inhibition by both SOD and catalase suggests that a Haber-Weiss reaction requiring both $\mathrm{O}_{2}^{-}$and $\mathrm{H}_{2} \mathrm{O}_{2}$ to generate $\mathrm{OH}$ - may account for part of the oxidation reaction. The Haber-Weiss mechanism depends on the demonstration of a role for $\mathrm{O}_{2}^{-}$and $\mathrm{H}_{2} \mathrm{O}_{2}$, e.g., inhibition by SOD and catalase, respectively. Although $\mathrm{O}_{2}{ }^{-}$production is relatively small compared to $\mathrm{H}_{2} \mathrm{O}_{2}$, there is still enough $\mathrm{O}_{2}^{-}$produced to stoichrometrically account for the oxidizing radical detected in a reaction with excess $\mathrm{H}_{2} \mathrm{O}_{2}$. On the basis of a demonstrated catalytic catalase and SOD effect, and sufficient quantities of both $\mathrm{H}_{2} \mathrm{O}_{2}$ and $\mathrm{O}_{2}{ }^{-}$produced, a Haber-Weiss mechanism is possible under these conditions.

These stimulus-dependent differences in ethylene generation could result from differences in oxidase activation and function, the relative rates of formation and degradation of the various oxygen metabolites involved, or the nature of the oxidizing radical species reacting with the KMB substrate. As an example of the first mechanism, NADPH oxidase is activated from its resting state by particulate or soluble stimuli operating through different triggering mechanisms (20) that could affect the enzyme or its membrane milieu in ways analogous to different reaction conditions for xanthine oxidase that change its ratio of $\mathrm{O}_{2}^{-}$and $\mathrm{H}_{2} \mathrm{O}_{2}$ production (21).

Second, the detectable appearance of free radical oxygen metabolites depends not only on their rate of formation, but also on their rates of degradation, which could also be stimulus-dependent. For highly reactive species the relative balance may be delicate, particularly in the case of oxidizing radicals, which constitute less than $1 \%$ of the neutrophils' oxygen reduction products. Relative differences in ethylene generation and cytochrome $c$ reduction have also been reported in neutrophils from human newborns and adults, which produce $\mathrm{O}_{2}^{-}$at equal rates but oxidizing radicals at lower rates in the newborns (1). In our studies, the linerity of ethylene production with neutrophil concentration fell off above $5 \times 10^{6}$ cells $/ \mathrm{ml}$ (26), suggesting an increasing role of degradation or competition at high cell concentrations.

Cell components may not only compete with KMB for oxidizing radicals, but also, by reacting with the radicals, contribute to the number and variety of species released into the medium. The subsequent reaction between the new species and KMB constitutes the third mechanism for stimulus-dependence postulated above. Kellogg and Fridovich have shown that $\mathrm{O}_{2}{ }^{-}$and $\mathrm{H}_{2} \mathrm{O}_{2}$ can initiate free radical chain reactions within cell membranes (15). The extent of these reactions would depend upon membrane fatty acid saturation and concentrations of endogenous scavengers, differences which might account for our observed differences between HL-60 and normal neutrophil free radical production. These reactions could transform $\mathrm{OH}$. into a variety of more complex organic free radicals, which may also react with KMB to release ethylene.

Although often cited as an assay for $\mathrm{OH} \cdot$, ethylene release from $\mathrm{KMB}$ is probably not specific for that oxidizing radical alone. The generation of ethylene from methional as an assay for $\mathrm{OH}$. was developed by Beauchamp and Fridovich, using xanthine plus xanthine oxidase as an enzymatic source of $\mathrm{O}_{2}{ }^{-}$and $\mathrm{H}_{2} \mathrm{O}_{2}$ (5). $\mathrm{KMB}$ was substituted for methional in studies with human neutrophils to circumvent the problems of auto-oxidation of methional (31), but the complex and varied oxidizing species of biologic systems capable of oxidizing methional may well oxidize $\mathrm{KMB}$ $(6,22)$. Our previous studies in fact show similar reactivities of each substrate by the scavenger profile (17), and therefore suggest that the problem of specificity is equally problematic for methional and $\mathrm{KMB}$ (32). Oxidation of dimethylsulfoxide to form ethane has also been employed to detect $\mathrm{OH} \cdot(23)$, but the specificity of this assay is as yet unconfirmed.

Rosen and Klebanoff (24) have suggested that ethylene generation in this assay may be a peroxidase mediated reaction, and report that electron spin resonance spectroscopy may serve as a more reliable assay of $\mathrm{OH} \cdot$; however, the technical difficulties of spintrapping $\mathrm{O}_{2}^{-}$and $\mathrm{OH} \cdot$ are well described, although 5,5-dimethyl-1-pyrroline-N-oxide (DMPO) is the most commonly employed spin trap for $\mathrm{OH}$ - in biologic systems, extensive methodologic precautions are required in its use (11). The $\mathrm{O}_{2}{ }^{-} / \mathrm{HO}_{2}$. adduct of DMPO is DMPO-OOH, which spontaneously decomposes into DMPO-OH and a nonradical species (10). The use of spin traps other than DMPO in electron spin resonance assay of $\mathrm{OH}$ - production by human neutrophils may be desirable because of the instability of the DMPO- $\mathrm{O}_{2}{ }^{-}$adduct, which is photolabile, oxygen sensitive, unstable at room temperature, and has a short half-life (25).

These technical difficulties emphasize the limitation of assigning a specific chemical identity to oxidizing species in complex biologic systems employing either chemical or spin trap substrates. Our studies suggest that the production of ethylene from KMB represents a common end point for heterogeneous pathways of KMB oxidation. Determination of the component $\mathrm{OH}$ - represented in this reaction is still unresolved and awaits direct identification of the various species generated from $\mathrm{O}_{2}{ }^{-}$.

\section{REFERENCES}

1. Ambruso, D. R., Altenburger, K. M., and Johnston, R. B., Jr.: Defective oxidative metabolism in newborn neutrophils: discrepancy between superoxide anion and hydroxyl radical generation. Pediatrics, 64: 722 (1979).

2. Ambruso, D. R. and Johnston, R. B., Jr.: Lactoferrin enhances hydroxyl radical production by human neutrophils, neutrophil particulate fractions and an enzymatic generating system. J. Clin. Invest., 67: 352 (1981).

3. Babior, B. M., Kipnis, R. S., and Curnutte, J. T. Biological defense mechanisms. The production of leukocytes of superoxide, a potential bactericidal agent. J. Clin Invest., 52: 741 (1973).

4. Babior, B. M.: Oxygen-dependent microbial killing by phagocytes. N. Engl. J. Med., 298: 659, 721 (1978)

5. Beauchamp, C, and Fridovich, I.: Mechanism for the production of ethylene from methional. Generation of the hydroxyl radical by xanthine oxidase. J. Biol. Chem., 215: 4641 (1970).

6. Bors, W., Lengfelder, E., Saran, M., Fuchs, C., and Michel, C.: Reactions of oxygen radical species with methional: A pulse radiolysis study. Biochem. Biophys. Res. Commun., 70: 81 (1976).

7. Collins, S. J., Ruscetti, F. W., Gallagher, R. E., and Gallo, R. C.: Terminal differentiation of human promyelocytic leukemia cells induced by diemthyl sulfoxide and other polar solvents. Proc. Natl. Acad. Sci. USA, 75: 2458 (1978).

8. Collins, S. J., Ruscetti, F. W., Gallagher, R. E., and Gallo, R. C.: Normal functional characteristics of cultured human promyeolocytic leukemia cells (HL-60) after induction of differentiation by dimethyl sulfoxide. J. Exp. Med., 149: 969 (1979).

9. Dorfman, L. M. and Adamas, G. E.: Reactivity of the hydroxyl radical in aqueous solutions. NSRDS-NBS. no. 46. U.S. Department of Commerce, National Bureau of Standards (1973).

10. Finkelstein, E., Rosen, G. M., and Rauckman, E. J.: Spintrapping of superoxide Mol. Pharm., 16: 676 (1979).

11. Finkelstein, E., Rosen, G. M., and Rauckman, E. J.: Spintrapping of superoxide and hydroxyl radical: Practical aspects. Arch. Biochem. Biophys., 200: 1 (1980).

12. Fontana, J. A., Wright, D. G., Shiffman, E., Corcoran, B. A., and Deisseroth, A B.: Development of chemotactic responsiveness in myeloid precursor cells: studies with a human leukemia cell line. Proc. Natl. Acad. Sci. USA, 77: 3664 (1980).

13. Hodgson, E. K. and Fridovich, I.: The production of superoxide radical during the decomposition of potassium peroxychromate (V). Biochemistry, 13: 3811 (1974).

14. Johnston, R, B. Jr., Keele, B. B. Jr., Misra, H. P., Lehmeyer, J. E. Webb, L. S., Baehner, R. L., and Rajagopalan, K. V.: The role of superoxide anion generation in phagocytic bactericidal activity: Studies with normal and chronic granulomatous disease leukocytes. J. Clin Invest., 55: 1357 (1975).

15. Kellogg, E. W. III and Fridovich, I.: Liposome oxidation and erythrocyte lysis by enzymatically-generated superoxide and hydrogen peroxide. J. Biol. Chem., 252: 6721 (1977)

16. Light, D. R., Walsh, C., O'Callaghan, A. M., Goetzl, E. J., and Tauber, A. I.: Characteristics of the cofactor requirments for the superoxide-generating NADPH oxidase of human polymorphonuclear leukocytes. Biochemistry, 20: 1468 (1981).

17. McCord, J. M. and Day, E. D., Jr.: Superoxide-dependent production of hydroxyl radical catalyzed by iron-EDTA complex. FEBS Lett., 86: 139 (1978).

18. Newburger, P. E., Chovaniec, M. E., Greenberg, J. S., and Cohen, H. J.: 
Functional changes in human leukemia cell line HL-60: a model for myeloid differentiation. J. Cell Biol., 82: 315 (1979).

19. Newburger, P. E., Chovaniec, M. E., and Cohen, H. J.: Activity and activation of the granulocyte superoxide-generating system. Blood, 55: 85 (1980).

20. Newburger, P. E., Pagano, J. S., Greenberger, J. S., Karpas, A., and Cohen, H. $\mathrm{J}$.: Dissociation of opsonized particle phagocytosis and respiratory burst activity in an Epstein-Barr virus-infected myeloid cell line. J. Cell Biol., 85: 549 (1980).

21. Olson, J. S., Ballou, D. P., Palmer, G., and Massey, V.: The mechanism of action of xanthine oxidase. J. Biol. Chem., 244: 4363 (1974).

22. Pryor, W. A. and Tang, R. H.: Ethylene formation from methaniol. Biochem. Biophys. Res. Commun., 81: 498 (1978).

23. Repine, J. E., Eaton, S. W., Anders, M. W., Hoidal, J. R., and Fox, R. B. Generation of hydroxyl radical by enzymes, chemicals and human phagocytes in vitro. Detection with the anti-inflammatory agent, dimethyl sulfoxide. J. Clin. Invest., 64: 1642 (1979).

24. Rosen, H. and Klebanoff, S.J.: Hydroxyl radical generation by polymorphonuclear leukocytes measured by electron spin resonance spectroscopy. J. Clin. Invest., 64: 1725 (1979).

25. Sanderson, D. G. and Chedekel, M. R. Spintrapping of the superoxide radical by 4-(N-methyl pyridinium) $t$-butyl nitrone. Photochem. Photobiol., 32: 573 (1980).

26. Tauber, A. I., Gabig, T. G., and Babior, B. M.: Evidence for hydroxyl radical production by human neutrophils. J. Clin. Invest., 60: 374 (1977).

27. Tauber, A. I. and Curnutte, J. T.: The dissociation of oxygen consumption from
$\mathrm{O}_{2}{ }^{-}$production in the human neutrophil. Blood, (Abstract), 52: 128 (1978).

28. Tauber, A. I. and Babior, B. M.: $\mathrm{O}_{2}^{-}$and host defense: the production and fate of $\mathrm{O}_{2}{ }^{-}$in neutrophils. Photochem. Photobiol., 28: 701 (1978).

29. Tauber, A. I., Gabig, T. G., and Babior, B. M.: Evidence for production of oxidizing radicals by the particulate $\mathrm{O}_{2}{ }^{-}$-forming system from human neutrohils. Blood, 53: 666 (1979).

30. Thurmon, R. G., Ley, H. G., and Scholz, R.: Hepatic microsomal ethanol oxidation. Hydrogen peroxide formation and the role of catalase. Eur. J. Biochem., 25: 420 (1972).

31. Weiss, S. J., Rustagi, P. T., and LoBuglio, A. F.: Human granulocyte generation of hydroxyl radical. J. Exp. Med., 147: 316 (1972).

32. Yang, S. F.: Further studies on ethylene formation from $\alpha$-keto- $\gamma$-methylthiobutyric acid or $\beta$-methylthiopropionaldehyde by peroxidase in the presence of sulfite and oxygen. J. Biol. Chem., 244: 4360 (1979).

33. The authors thank Dr. Harvey J. Cohen for helpful discussion and suggestions, Ms. Rachel Gorer for atomic absorption spectroscopy studies, and Ms. Susan Hansen and Ms. Angela M. O'Callaghan for technical assistance.

34. Requests for reprints should be addressed to: Alfred I. Tauber, M.D., 818 Harrison Ave., Boston, MA 02118.

35. This research was supported by Grants Al-18175, RR05712, and R23-AM31097 from the National Institutes of Health and a Basil O'Connor Starter Research Grant from the March of Dimes Birth Defects Foundation.

36. Received for publication October 21, 1981.

37. Accepted for publication April 14, 1982. 